\title{
Variability of the Initial Abstraction Ratio in an Urban and an Agroforested Catchment
}

\author{
Adam Krajewski ${ }^{1, *(\mathbb{D}}$, Anna E. Sikorska-Senoner ${ }^{2}{ }^{-}$, Agnieszka Hejduk ${ }^{3}{ }^{(-)}$and \\ Leszek Hejduk ${ }^{1}$ (iD \\ 1 Department of Water Engineering and Applied Geology, Warsaw University of Life Sciences-SGGW, \\ Nowoursynowska 159, 02-776 Warsaw, Poland; leszek_hejduk@sggw.pl \\ 2 Department of Geography, University of Zurich, Winterthurerstrasse 190, 8057 Zürich, Switzerland; \\ anna.sikorska@geo.uzh.ch \\ 3 Water Center of Warsaw University of Life Sciences-SGGW, Ciszewskiego 6, 02-776 Warsaw, Poland; \\ agnieszka_hejduk@sggw.pl \\ * Correspondence: adam_krajewski1@sggw.pl
}

Received: 28 November 2019; Accepted: 31 January 2020; Published: 4 February 2020

check for updates

\begin{abstract}
The Curve Number method is one of the most commonly applied methods to describe the relationship between the direct runoff and storm rainfall depth. Due to its popularity and simplicity, it has been studied extensively. Less attention has been given to the dimensionless initial abstraction ratio, which is crucial for an accurate direct runoff estimation with the Curve Number. This ratio is most often assumed to be equal to 0.20 , which was originally proposed by the method's developers. In this work, storm events recorded in the years 2009-2017 in two small Polish catchments of different land use types (urban and agroforested) were analyzed for variability in the initial abstraction ratio across events, seasons, and land use type. Our results showed that: (i) estimated initial abstraction ratios varied between storm events and seasons, and were most often lower than the original value of 0.20; (ii) for large events, the initial abstraction ratio in the catchment approaches a constant value after the rainfall depth exceeds a certain threshold value. Thus, when using the Soil Conservation Service-Curve Number (SCS-CN) method, the initial abstraction ratio should be locally verified, and the conditions for the application of the suggested value of 0.20 should be established.
\end{abstract}

Keywords: Curve Number; initial abstraction ratio; direct runoff; SCS-CN method; small catchment

\section{Introduction}

Estimation of the direct runoff as a catchment response to a rainfall or snowmelt event is important for many practical applications: The direct runoff is the key variable used for designing hydraulic structures [1], estimating soil erosion and sediment yield [2], or analyzing long-term changes in water resources availability [3]. The amount of water outflowing after a storm event depends on, among others, the catchment topography, land cover, soil characteristics, and climate conditions. Hence, for a specific site, the amount of direct runoff may vary significantly over successive years but also from one storm event to another within the same year [4]. This relationship between the direct runoff and the storm rainfall depth may be assumed constant given the same rainfall depth and unchanged catchment conditions.

One of the most commonly applied methods to describe this relationship between the direct runoff and storm rainfall depth is the Soil Conservation Service-Curve Number (SCS-CN), developed by the United States Department of Agriculture (USDA) [5]. Despite its simplicity, this method accounts for most of the catchment runoff characteristics responsible for producing the direct runoff such as soil type; land use and treatment; and surface and antecedent moisture conditions. Moreover, its parameter 
(i.e., curve number, $C N$ ) can be derived directly from physical properties of the catchment or from recorded rainfall-runoff events [6]. Therefore, the SCS-CN method remains very attractive for runoff estimation in poorly gauged regions, in applied hydrology for engineering designs, or in post analysis of recorded data $[7,8]$, where the simplicity and the universality of the method play a deciding role. As this method estimates only the direct runoff without considering the base flow component, it is most often applied to event-based models [9]. According to SCS-CN, the relationship between the rainfall depth, direct runoff, and catchment retention can be described as follows:

$$
\frac{H}{P-I a}=\frac{F}{S}
$$

where:

F: actual catchment retention (mm),

$S$ : potential maximum catchment retention $(\mathrm{mm})$,

$H$ : direct runoff, effective rainfall $(\mathrm{mm})$,

$P$ : rainfall depth $(\mathrm{mm})$,

$I a$ : initial abstraction $(\mathrm{mm})$.

Note that, $F \leq S$ and $H \leq(P-I a)$. The total retention for a storm consists of both $I a$ and $F$, so the conservation of the mass Equation can be expressed as:

$$
F=P-I a-H
$$

Substituting Equation (2) for $F$ in Equation (1) and solving it for the direct runoff results in:

$$
H=\frac{(P-I a)^{2}}{P-I a+S}
$$

The initial abstraction $(\mathrm{Ia})$ consists of evaporation, interception, infiltration, and surface depression storage. If rainfall depth is lower or equal to the initial abstraction, the direct runoff is assumed to be zero (i.e., all rainfall water is used to fill the catchment retention). According to the National Engineering Handbook [5], an empirical relationship between $I a$ and $S$ has been established as:

$$
I a=\lambda \times S
$$

where $\lambda$ is the initial abstraction ratio (-).

The potential maximum catchment retention $(S)$ is next calculated from the following formula:

$$
S=25.4\left(\frac{1000}{C N}-10\right)
$$

where $\mathrm{CN}$ is curve number, i.e., the only parameter (-) of the SCS-CN method that depends on soil characteristics, land use, and catchment initial conditions prior to the storm event.

Due to its popularity, the SCS-CN method has been the object of many studies. These studies focused on application of the method, e.g., in rainfall-runoff modelling [10], analyzing the impact of land use changes such as urbanization on runoff values [11], predicting sediment yield [12,13], as well as on the estimation and verification of the $C N$ parameter [14-17]. Yet, less attention has been given to the dimensionless initial abstraction ratio $(\lambda)$, and most often this ratio was assumed equal to 0.20, as it was originally proposed by method's developers [5]. Although Woodward et al. [18] have suggested based on intensive data of 327 US catchments that a value of 0.05 may be more appropriate than 0.2 , most of the applied studies continued to use the originally proposed value of 0.2 . Recently, this dimensionless initial abstraction ratio $(\lambda)$ has gained much more attention and several researchers have revealed that (a) this ratio may vary widely for specific sites $[19,20]$, and (b) it may be significantly lower than $0.20[18,21,22]$. A change in the initial abstraction ratio from a fixed value of 0.20 to a 
lower value will strongly affect the estimated depth of the direct runoff and consequently the direct runoff distribution over time. Durán-Barroso et al. [23] have even stated this relationship between the initial abstraction and the maximum potential catchment retention as being one of the major sources of uncertainty in the SCS-CN method. Hence, some researchers have tried to estimate the value of this ratio from recorded storm data, and they concluded that using a varying value of the initial abstraction ratio rather than a fixed value of 0.2 or even 0.05 significantly improves runoff estimates $[9,20,23]$. Nevertheless, the number of studies devoted to the initial abstraction ratio is still very limited. As this ratio was also declared as being regional specific [18], more research is needed for catchments in different climatic regions to investigate properties of this ratio.

Another important aspect of the initial abstraction ratio is linked with the basic assumption of the SCS-CN method that both this ratio and the $C N$ parameter are assumed constant given that catchment conditions do not change. Yet, any change in the catchment conditions will affect the relationship between the storm rainfall depth and the direct runoff amount, and consequently the value of the $\mathrm{CN}$ parameter and possibly the initial abstraction ratio. In this respect, direct human activities such as land use changes and human induced climate changes are considered as two major factors that affect runoff processes the most. Many studies have tried to quantify their role in the hydrological cycle [24-26]. For instance, Chen et al. [27] revealed that for a large basin (area $=18,827 \mathrm{~km}^{2}$ ) in northwestern China, climate variability was the major factor affecting the runoff amount, accounting for $90.5 \%$ of the increase in the runoff amount, while other human activities accounted only for $9.5 \%$ of the runoff increase. In contrast to that, $\mathrm{Lv}$ et al. [28] found for the same region that in the case of a small catchment (area $=72.8 \mathrm{~km}^{2}$ ), climate change accounted only for about $33 \%$ of the total decrease in mean annual runoff, while direct human activity was responsible for about $67 \%$ of the decrease in mean annual runoff. Tan and Gan [29], based on investigations in 96 Canadian catchments, showed that climate change generally caused an increase in the mean annual runoff, while direct human impacts usually lead to decreasing water resources. These studies indicate how complex interactions between climatic, anthropogenic, and hydrological variables are, and how difficult it is to evaluate their individual impacts on the hydrological cycle in the catchment [30]. Although these climatic and direct anthropogenic factors can be accounted for in the SCS-CN method by simply adjusting the curve number $(C N)$, it remains unclear whether and how exactly these factors may affect the value of the initial abstraction ratio in the SCS-CN method.

In this work, recorded rainfall-runoff data collected in the years 2009-2017 in two small Polish catchments of different land use types (urban and agroforested) were analyzed in order to a) estimate and verify the value of the initial abstraction ratio in these two catchments for different storm events, b) analyze the variation of the initial abstraction ratio with the rainfall depth, and c) explore (indirectly) the effect of the land use type and season on the initial abstraction ratio value in this climatic region. The main focus of this study is to investigate such local estimates of the initial abstraction ratio based on limited recorded storm events for two small catchments of different land use types. This study is a follow-up of two previous studies conducted for these two catchments $[14,31]$ that investigated the applicability of the SCS-CN method and estimated the $C N$ parameter values based on conventional methods. Therefore, the estimation of the $\mathrm{CN}$ and its verification are not the main subjects of this study.

\section{Materials and Methods}

\subsection{Characteristics of the Study Catchments}

Data analyzed in this work were collected in two small catchments of different land use types: urban at Służew Creek and agroforested at Zagożdżonka River (Figure 1). In both of them, meteorological and hydrological variables are automatically monitored by the Department of Water Engineering and Applied Geology (DoWEaAG) of Warsaw University of Life Sciences-SGGW (WULS-SGGW). Table 1 presents basic topographic and climatic characteristics of both study sites. Both of these catchments are under human pressure. In the urban catchment of Służew Creek, for the last 40 years an increase of 
impervious areas has been observed, which, among others, leads to a higher flood risk [32]. In the agroforested catchment of Zagożdżonka River, decreasing trends in low and medium discharges have been observed [3]. Research on the rainfall-runoff process under the above mentioned conditions is particularly valuable as it helps to manage water resources in a changing environment.

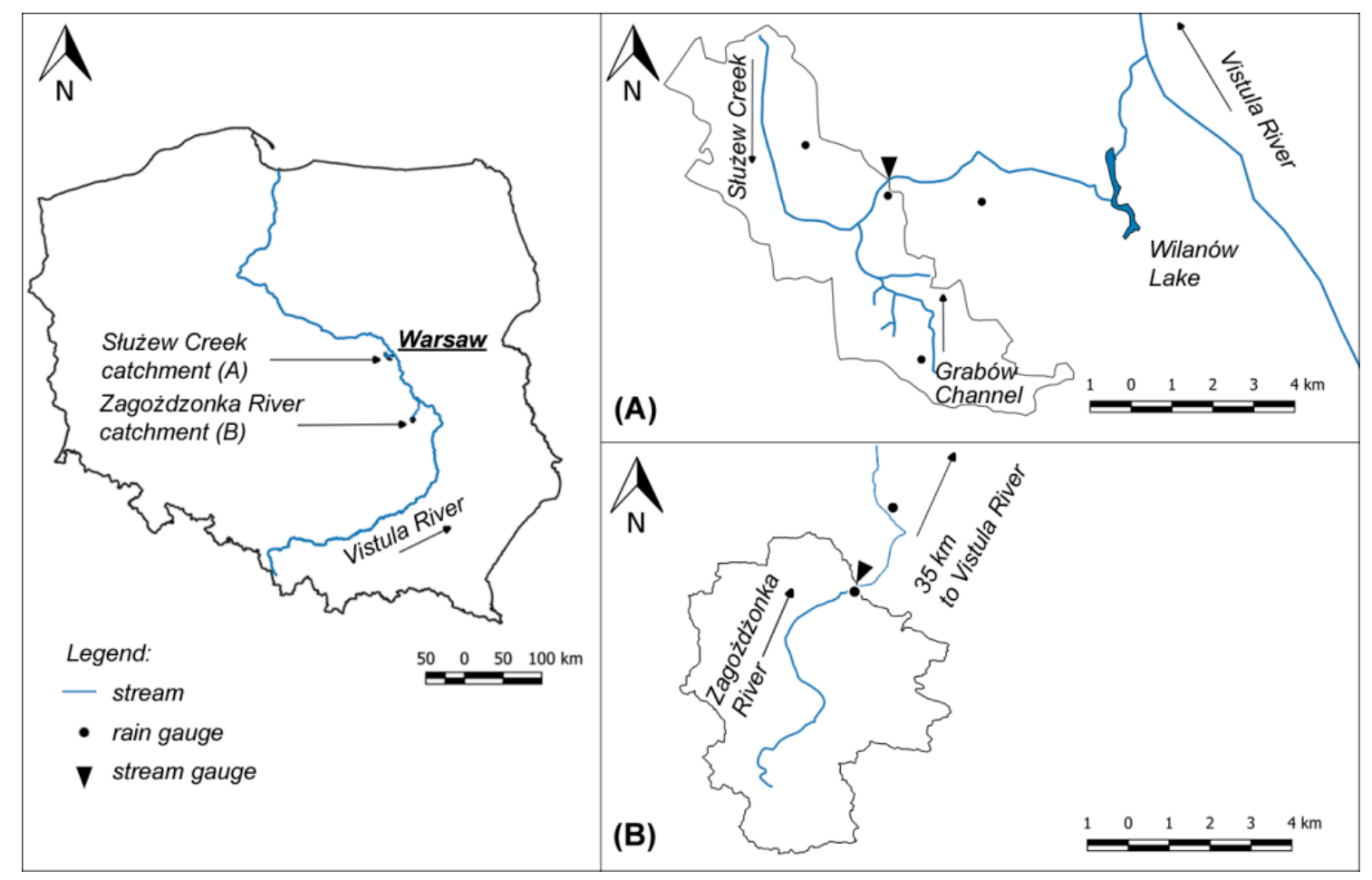

Figure 1. Locality map of Służew Creek (A) and Zagożdżonka River (B) catchments up to the Wyścigi and Czarna gauging stations, respectively.

The first catchment, Służew Creek, is located in the southwestern part of Warsaw in Poland. Its total area equals $54.8 \mathrm{~km}^{2}$, whereas the subcatchment up to Wyścigi gauging station (analyzed in this work) has an area of $28.7 \mathrm{~km}^{2}$. This catchment has heterogeneous land use (see Table 2 for details) with more than $60 \%$ of its area covered by built-up areas and with the impervious factor of the total catchment reaching up to $25 \%$. Fine-grained soils dominate the watershed area. Previous investigations conducted in the Służew Creek catchment were related to urban hydrology with a focus on flood flow estimation [33,34] and operation of small detention ponds for flood and sediment load reduction $[35,36]$ or sediment transport $[37,38]$. The climate in Poland is continental and in the case of the analyzed study site it may be described as moderate. Long-term measurements indicate that the average annual precipitation is $541.9 \mathrm{~mm}$ [39] and the average annual temperature is $8.6^{\circ} \mathrm{C}$ [40]. The average annual discharge at Wyścigi gauging station in the analyzed period (2009-2017) was $0.182 \mathrm{~m}^{3} \mathrm{~s}^{-1}[41]$.

The second analyzed catchment, Zagożdżonka River, is a left tributary of the Vistula River. Its catchment is located in central Poland, about $100 \mathrm{~km}$ south of Warsaw (Figure 1). Hydrological research in the upper part of the Zagożdżonka River has been conducted by WULS-SGGW since the 1960s. It was initiated to determine the water needs of the chemical plant. Over time, the scope of investigation has expanded $[2,4,10,31]$, and currently there are two stream gauging stations, at Płachty Stare (since 1962) and Czarna (since 1991), at which measurements of basic meteorological and hydrological parameters are carried out continuously. In contrast to the urban catchment mentioned above, the Zagożdżonka River catchment can be defined as agricultural and forested. The catchment area at Czarna (considered in this study) is equal to $23.4 \mathrm{~km}^{2}$. Forests (45\%) and arable lands ( $\left.43 \%\right)$ 
cover a significant part of the catchment area (see Table 2 for details). Sandy soils are the major soil type in this catchment, while in local depressions and river flood plains, peaty soils may be found.

Table 1. Topographic and climatic characteristic of investigated catchments.

\begin{tabular}{cccc}
\hline Category & Unit & $\begin{array}{c}\text { Służew Creek (Years) } \\
\text { [Source] }\end{array}$ & $\begin{array}{c}\text { Zagożdżonka River (Years) } \\
\text { [Source] }\end{array}$ \\
\hline Catchment type & - & lowland, urbanized & lowland, agroforested \\
Area up to gauging station & $\mathrm{km}^{2}$ & $28.7[41]$ & $23.4[41]$ \\
Average channel slope & $\% o$ & $1.1[41]$ & $3.0[41]$ \\
Impervious surfaces & $\%$ & $25.3[42]$ & $0.56[42]$ \\
Average precipitation & $\mathrm{mm}$ & $541.9(1960-2009)[39]$ & $612.0(1963-2015)[3]$ \\
Average temperature & ${ }^{\circ} \mathrm{C}$ & $8.6(1970-2009)[40]$ & $8.1(1951-2015)[3]$ \\
Average discharge per sq. $\mathrm{km}$ & $\mathrm{dm}^{3} \cdot \mathrm{s}^{-1} \cdot \mathrm{km}^{-2}$ & $6.34(2010-2017)[41]$ & $3.89(2010-2017)[41]$ \\
\hline
\end{tabular}

Table 2. Land cover and soil types in the Służew Creek catchment up to Wyścigi gauging station and in the Zagożdżonka River catchment up to Czarna station.

\begin{tabular}{ccc}
\hline \multirow{2}{*}{ Category } & \multicolumn{2}{c}{ Land Cover (\%) and Soil Structure (\%) in } \\
\cline { 2 - 3 } & Służew Creek & Zagożdżonka River \\
\hline Land cover type [42] & \\
\hline Residential areas & 28.9 & 3.6 \\
Airport & 19.3 & - \\
Arable lands & 12.9 & 43.4 \\
Forests & 12.5 & 45.1 \\
Industrial areas & 9.4 & - \\
Recreation areas & 7.9 & - \\
Roads and associated lands & 7.1 & - \\
Meadows & 2.0 & - \\
\hline & Soil type [43] & - \\
\hline Loamy sand & 50.5 & - \\
Light loamy sand & 40.2 & 67.8 \\
Organic soil & 9.3 & 27.3 \\
Silt loam & - & 4.9 \\
Silt & - & \\
Sand & - &
\end{tabular}

The relief in both catchments is typical for lowlands in Poland with an insignificant elevation variation. Thus, the catchment elevation does not play any relevant role in the runoff generation in these two catchments.

\subsection{Recorded Data}

Hydrological field investigations were carried out in both catchments according to the standard methodology recommended by the Polish Institute of Meteorology and Water Management, National Research Institute [44,45]. Rainfall depths were measured with the use of tipping-bucket rain gauges at four locations in the Służew Creek catchment and two in the Zagożdżonka River catchment. Recorded rainfall depths were summed up in 10 min intervals and the average rainfall over the catchment was calculated according to the Thiessen polygons method. River gauging stations at catchments outlets were equipped with staff gages and automatic, pressure water stage loggers. At these river gauging stations, water stages data were collected every $10 \mathrm{~min}$. In order to estimate and verify the automated measurements, readings of the gage staff were regularly performed at least once a week. Recorded water levels were next converted to discharge values with the help of the rating curve method [46]. The rating curves were established at both sites with numerous hydrometric measurements, i.e., cross 
section area and flow velocity, conducted at low, medium, and high stages. These curves were verified each year to reduce the uncertainty in the rating curve method [3].

\subsection{Selection of Storm Rainfall-Runoff Events}

From all rainfall events recorded in the years 2009-2017, we selected only those events that generated a direct runoff. All of these events were caused by rainfall events in the spring-summer seasons. This criterion led to a selection of 53 storm events in the Służew Creek, and 42 storm events in the Zagożdżonka River, respectively, with an average direct runoff of about $3 \mathrm{~mm}(2.9 \mathrm{~mm}$ in Zagożdżonka River). The average rainfall depth of selected events was equal to $22.8 \mathrm{~mm}$ in the Służew Creek and to $25.8 \mathrm{~mm}$ in the Zagożdżonka River.

Antecedent moisture conditions (AMC) were estimated for all 95 events (see Table 3). Within these events, 85 were classified as AMC I, seven as AMC II, and three as AMC III. Therefore, it can be stated that the majority of recorded events occurred during dry conditions. This finding is surprising because the analyzed period 2009-2017 was not extremely dry or less rich in water compared to previous years [47]. Thus, it is likely that the thresholds used to determine moisture conditions may not correspond to the climate of central Poland and should be adapted for this region in a future study.

Table 3. Antecedent moisture condition (AMC) for analyzed events according to the Soil Conservation Service-Curve Number method.

\begin{tabular}{ccc}
\hline \multirow{2}{*}{ Antecedent Moisture Condition } & \multicolumn{2}{c}{ Total Number of Events with 5 Days of Rainfall for } \\
\cline { 2 - 3 } & Dormant Period & Vegetation Period \\
\hline AMC I & $(12$ events $)<13 \mathrm{~mm}$ & $(73$ events $)<35 \mathrm{~mm}$ \\
AMC II & $13 \mathrm{~mm} \leq(3$ events $) \leq 28 \mathrm{~mm}$ & $35 \mathrm{~mm} \leq(4$ events $) \leq 53 \mathrm{~mm}$ \\
AMC III & $(1$ event $)>28 \mathrm{~mm}$ & $(2$ events $)>53 \mathrm{~mm}$ \\
\hline
\end{tabular}

\subsection{Estimation of the Initial Abstraction Ratio from Recorded Data}

The initial abstractions were estimated based on recorded storm events (see Figures 2 and 3 ) as the sum of the rainfall depth after which a direct runoff begins (seen as an increase in water stage and river discharge). The volume of the direct runoff was calculated based on the measured hydrograph, e.g., by indicating the event start point (increase in river discharge after the rainfall begins), the event end point (change in the slope of the hydrograph falling limb), and by removing the base flow from the total runoff. The base flow was estimated following the straight-line separation method that is described in detail by Wanielista et al. [48]. The computed volume of the direct runoff was next divided by the catchment area, giving the runoff depth for each storm event. As the rainfall depth, the direct runoff, and the initial abstraction are known (measured or estimated), Equation (3) may be solved for the maximum potential catchment retention: $S$. Finally, the initial abstraction ratio was computed from Equation (4) for each recorded storm event. This technique of Ia estimation has been used in previous studies such as Shi et al. [8] and Ling et al. [49].

The estimated values for the initial abstraction ratio were compared with the original value of 0.2 that was suggested in the original version of the SCS-CN method [5]. 


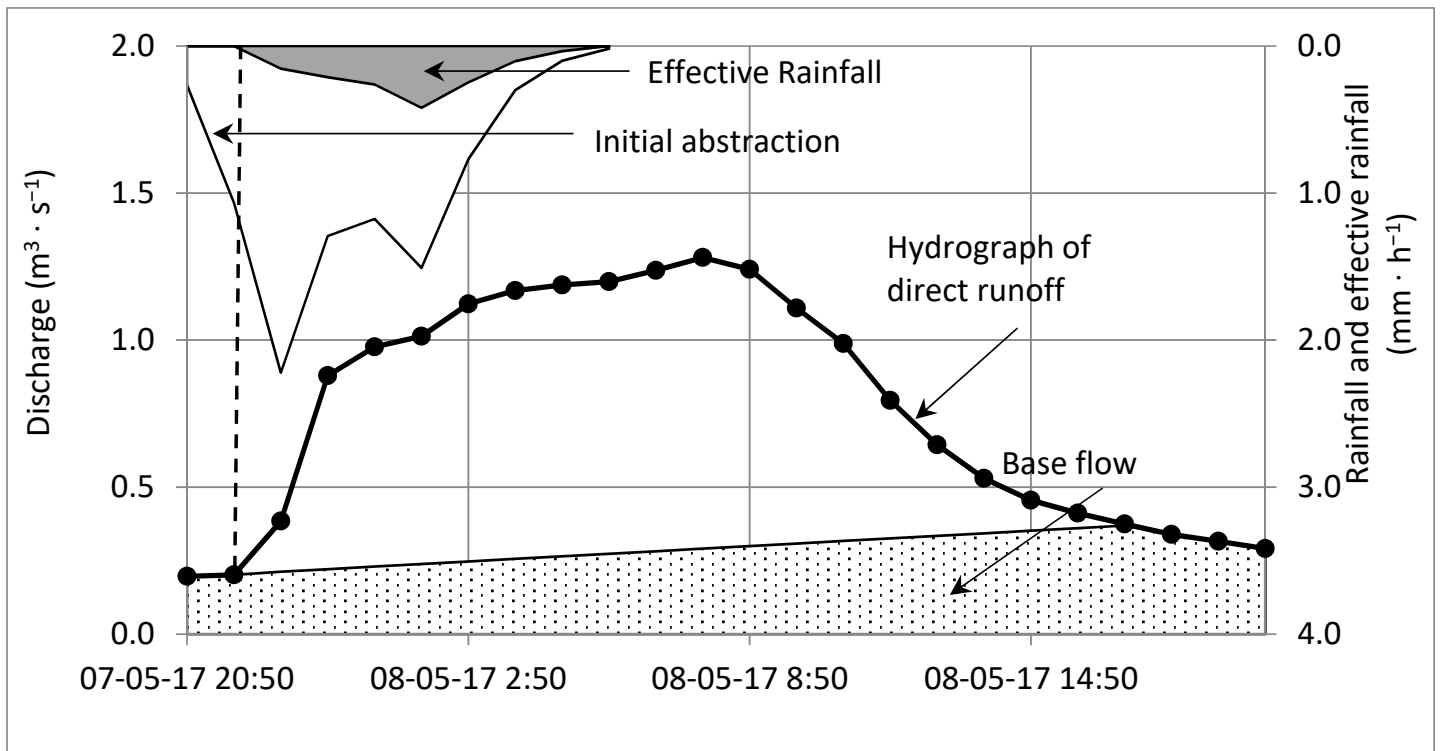

Figure 2. Example of the rainfall-runoff event, 7 May 2017, recorded in the Służew Creek catchment.

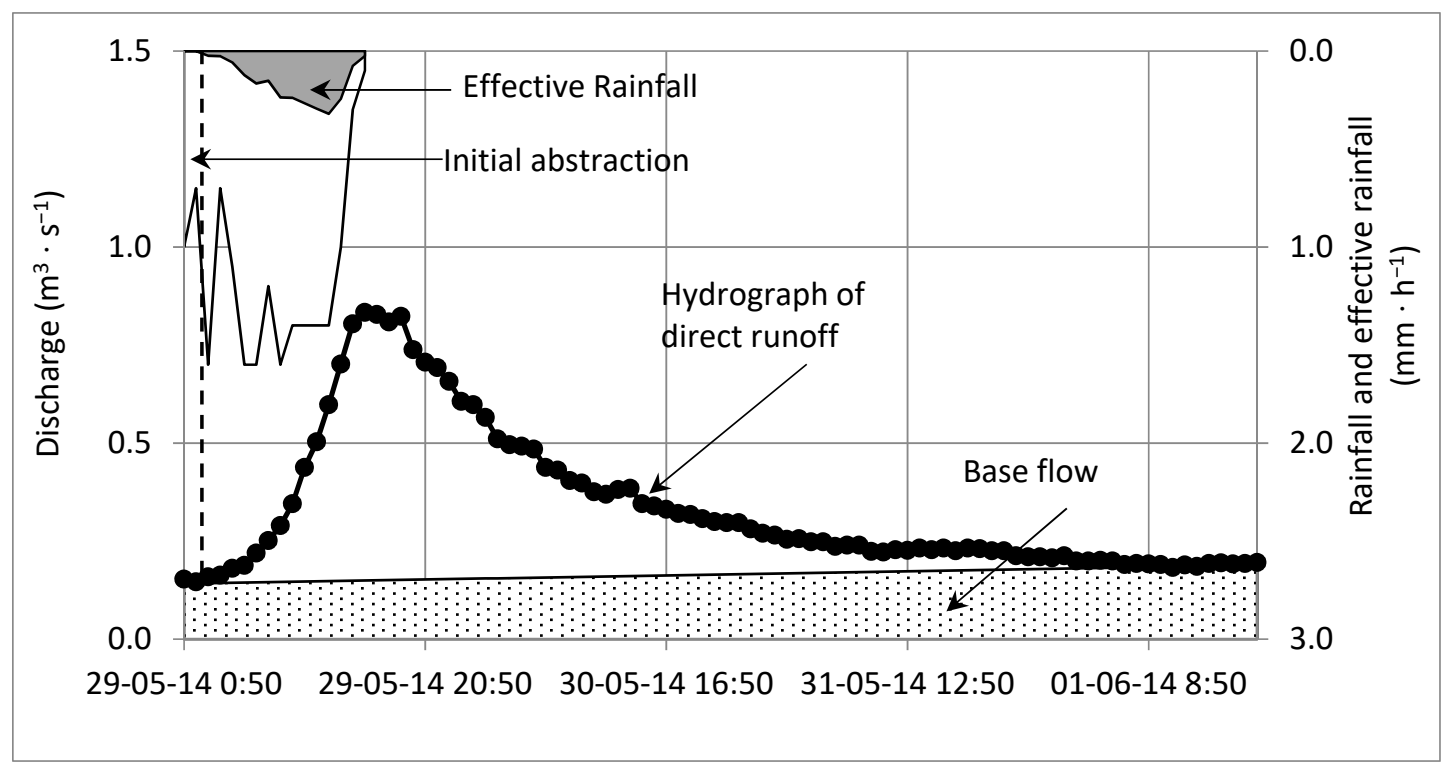

Figure 3. Example of the rainfall-runoff event, 29 May 2014, recorded in the Zagożdżonka River catchment.

\subsection{Variability of the Initial Abstraction Ratio}

In order to investigate seasonal variation in the initial abstraction ratio due to the state of the vegetation development and other seasonal factors, the recorded storm events were next grouped into three periods: (I) beginning of the vegetation season (April-May), (II) full vegetation state (June-August), and (III) end of the vegetation season and plants resting period (September-March). The analysis of the initial abstraction ratio was performed for all events in each group separately and the estimated values for each group were compared.

Finally, we investigated whether a relationship between the initial abstraction ratio and the rainfall depth can be established for our recorded data. The relationship between the $C N$ parameter and the rainfall depth has been explored [14,31,50]. Among others, Soulis and Valiantzas [51,52] studied the effect of soils and land cover variability on the hydrologic response and proposed a methodology to determine the spatial distribution of the SCS-CN parameter values from rainfall-runoff data. However, 
similar analyses of the initial abstraction ratio have rarely been performed $[8,20]$ and did not reveal any relationships between these two variables. In our case, we focused only on summer events (i.e., from May to September), to reduce the possible effect of the seasonal variability in the ratio in the studied catchments and also because most of the recorded events occurred during this period.

The relationship between the initial abstraction ratio and the rainfall depth has been approximated with an asymptotic formula:

$$
\lambda(P)=\lambda_{\infty}+\left(1-\lambda_{\infty}\right) \exp \left(-\frac{P}{b}\right)
$$

where:

$\lambda \infty$ : initial abstraction ratio (-) for rainfall tending to infinity,

$P$ : rainfall depth $(\mathrm{mm})$,

$b$ : constant parameter (-).

Parameters in Equation (5) were next identified using the Table Curve 2D software [53].

\section{Results and Discussion}

\subsection{Initial Abstraction Ratio Variation}

Characteristics of the selected storm events for both catchments are summarized in Table 4 . In the Służew Creek catchment, recorded rainfall depths ranged from $4.3 \mathrm{~mm}$ up to almost $76 \mathrm{~mm}$, with the average runoff coefficient (ratio of rainfall to runoff) equal to 0.125 . The estimated initial abstraction ratio $(\lambda)$ for all recorded events varied from 0.002 to 0.188 and thus was lower than the original value of 0.20 . The $\lambda$ average value over all 53 analyzed storm events was equal to 0.026 .

Table 4. Characteristics of rainfall-runoff events recorded in the catchments of Służew Creek and Zagożdżonka River.

\begin{tabular}{ccccccc}
\hline \multirow{2}{*}{ Category } & \multirow{2}{*}{ Abbr. } & \multirow{2}{*}{ Unit } & \multicolumn{2}{c}{ Służew Creek } & \multicolumn{2}{c}{ Zagożdżonka River } \\
\cline { 5 - 7 } & & & Range & Average & Range & Average \\
\hline No. of events & $\mathrm{n}$ & - & - & 53 & - & 42 \\
Rainfall depth & $P$ & $\mathrm{~mm}$ & $4.3-75.8$ & 22.8 & $5.8-145.1$ & 25.8 \\
Direct runoff & $H$ & $\mathrm{~mm}$ & $0.2-16.3$ & 3.0 & $0.2-21.8$ & 2.9 \\
Runoff coefficient & $\mathrm{c}=H / P$ & - & $0.053-0.295$ & 0.125 & $0.018-0.577$ & 0.106 \\
Initial abstraction & $I a$ & $\mathrm{~mm}$ & $0.1-4.8$ & 2.2 & $0.4-12.5$ & 3.7 \\
Maximum potential & $S$ & $\mathrm{~mm}$ & $23.4-683.3$ & 151.3 & $9.1-1342$ & 280.4 \\
catchment retention & $\mathrm{S}$ & - & $0.002-0.188$ & 0.026 & $0.001-0.512$ & 0.047 \\
Initial abstraction ratio & $\lambda=I a / S$ & - & & & &
\end{tabular}

In the case of the Zagożdżonka River catchment, rainfall depths varied from $5.8 \mathrm{~mm}$ to $145.1 \mathrm{~mm}$, with the average runoff coefficient estimated as 0.106 . The average initial abstraction ratio in the Zagożdżonka River catchment over all 42 storm events was equal to 0.047, which was almost twice as high as in the Służew Creek catchment but still lower than 0.20. For individual events, $\lambda$ varied from 0.001 to 0.512 . Among all analyzed storm events, only for two events was $\lambda$ higher than 0.2 , while for all other 40 events it was below this original value.

The values of $\lambda$ for individual events are presented in Figure 4 . In the case of the Zagożdżonka River, the data are more dispersed, meaning that the variation in $\lambda$ for different storm events was higher than for the Służew Creek catchment. However, whereas the mean values varied for both catchments, the median values are similar, i.e., 0.017 and 0.018, respectively, for Służew Creek and Zagożdżonka River. 


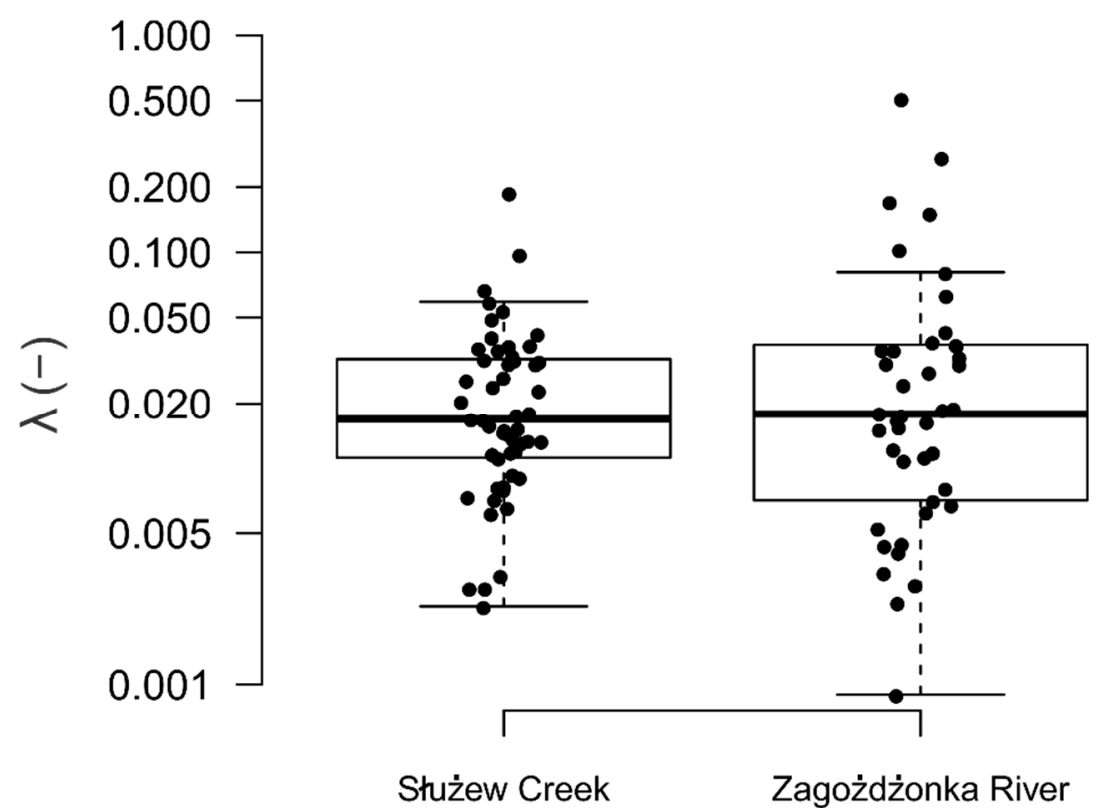

Figure 4. Distribution of initial abstraction ratios $(\lambda)$ for two analyzed catchments; note the logarithmic scale.

These findings demonstrate that for both catchments the initial abstraction ratio $\lambda$ varyied for different storm events, and for most storm events it was lower than the original value of 0.2 suggested by the authors of [5] and often even lower than 0.05, which was proposed as a modification of the originally developed method [18]. Similar results were reported by other researchers $[9,20,23]$, who also used a varying value for $\lambda$ in their studies. These findings suggest that using a varying value of $\lambda$ may indeed be more appropriate than a constant fixed value for all events.

\subsection{Initial Abstraction Ratio Dependency on the Land Use Type}

The Zagożdżonka River catchment with $96 \%$ of undeveloped areas (forests, meadows, arable lands) has a much higher retention capacity than does the Służew Creek catchment, where undeveloped areas cover only $35 \%$. Thus, as the elevations of these catchments do not play any role in the runoff generation, we can conclude that the value of $\lambda$ depends on the land use type in the catchment and it decreases with an increasing ratio of the catchment imperviousness. Thus, it is logical that the value of $\lambda$ is smaller than 0.2 in the urbanized catchment of Służew Creek. It is surprising, however, that even in the Zagożdżonka catchment that has a high proportion of forests and meadows (53\%) the ratio $\lambda$ did not reach the original value of 0.20 .

\subsection{Initial Abstraction Ratio Dependence on the Vegetation State}

As it appears from our results in Section 3.2, the initial abstraction ratio can be related to the dominant land use in the catchment. Hence, its value may also change seasonally due to the state of the vegetation development. Figure 5 presents the variability of initial abstraction ratio within the three investigated seasons in both studied catchments, i.e., (I) beginning of the vegetation season (April-May); (II) full vegetation state (June-August); and (III) end of the vegetation season and plants resting period (September-March).

In the case of the Zagożdżonka River catchment a noticeable increase in the value of $\lambda$ may be noticed for the vegetation period (May-September). During the full vegetation period, rainfall depths were intercepted by plants and initial abstractions were the greatest. For the Służew Creek catchment, no relevant change in the ratio was observed and the ratio value seemed to be relatively constant over time. The small percentage of vegetation in this catchment, which is dominated by the 
urban area instead, probably limits the role of the interception in the runoff formation. Hence, we can conclude that the seasonal variability in the initial abstraction ratio can be observed only in a catchment where vegetation plays a role. Depending on the vegetation type and its percentage in the catchment, this factor may need to be accounted for when estimating the initial abstraction ratio in agricultural or forested catchments. No variation in the ratio should be expected in urbanized or highly impervious catchments and an average value for the ratio over all seasons could be used.

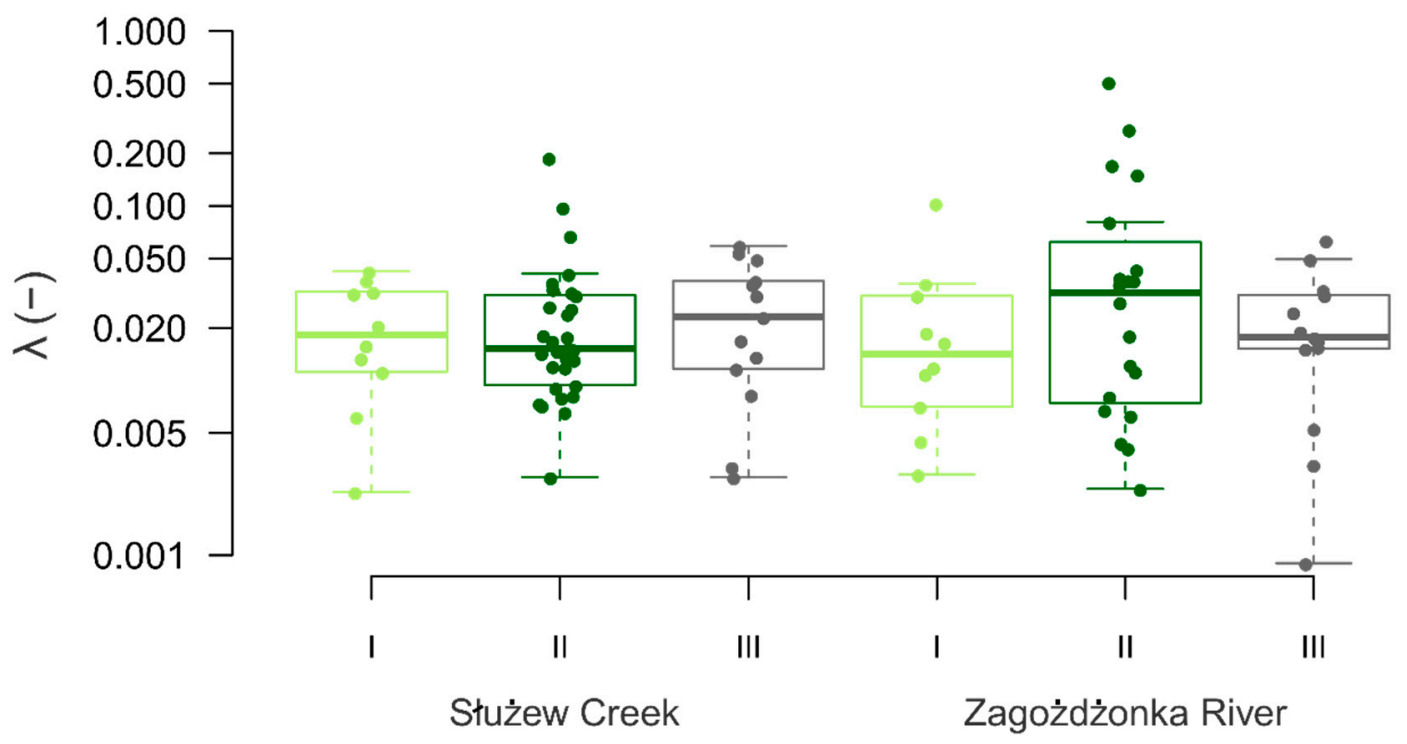

Figure 5. Changes in initial abstraction ratios within vegetation seasons for two analyzed catchments; note the logarithmic scale.

\subsection{Initial Abstraction Ratio Variation with Rainfall Depth}

In the case of the Służew Creek catchment, 43 storm events occurred during the summer period (May-September) and the estimated values of the initial abstraction ratio for these events have been plotted versus rainfall depths in Figure 6. Although the variability of $\lambda$ with rainfall depth was high, for rainfall depths higher than $30 \mathrm{~mm}$, the initial abstraction ratio seemed to be relatively constant and varied about the value of 0.0089 .

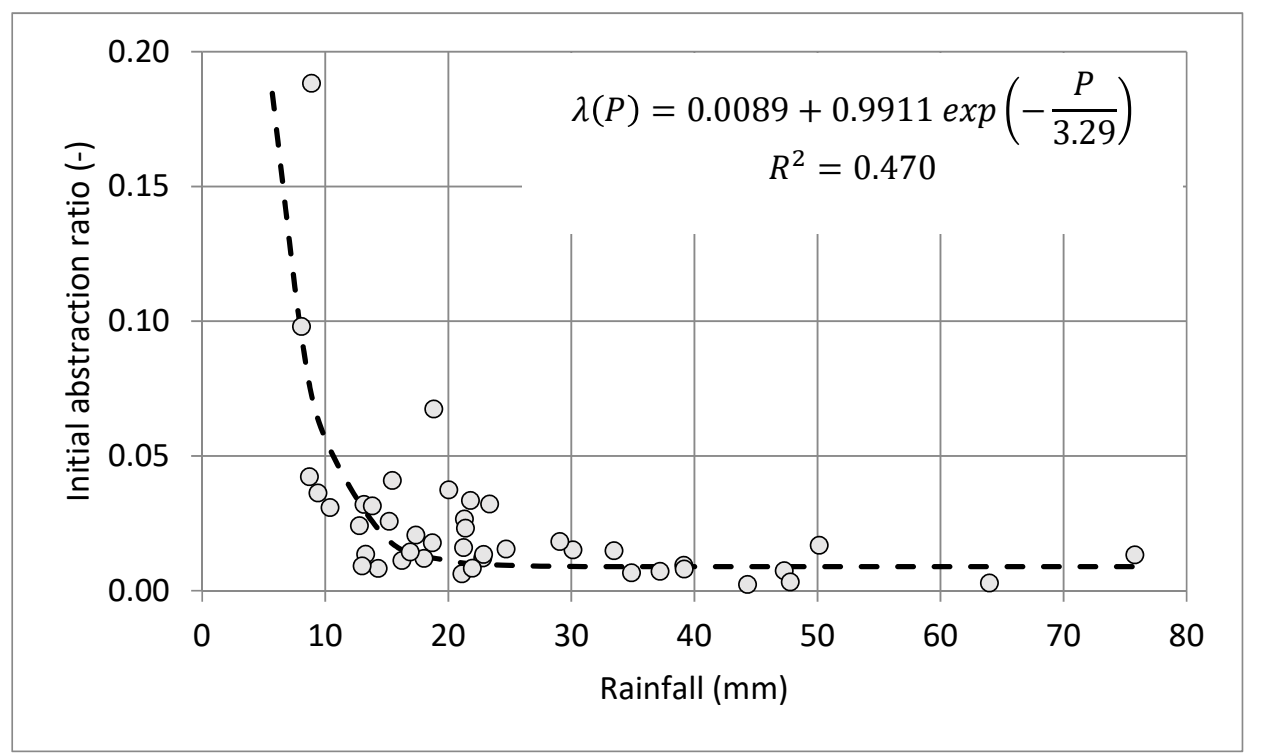

Figure 6. Initial abstraction ratio vs. rainfall depth for summer period, Służew Creek catchment. 
The same procedure was repeated for the Zagożdżonka River, resulting in 32 summer events and the results are plotted in Figure 7. In this catchment, a greater variation of $\lambda$ (especially for low rainfalls) was observed than for that in the Służew Creek catchment (compare with Figure 6). Although the relationship between the initial abstraction ratio and the rainfall depth was in this catchment less pronounced, a similar tendency to the Służew Creek catchment could also be observed here, i.e., a constant value of the initial abstraction ratio approaching 0.0109 for rainfalls with the rainfall depth higher than $20 \mathrm{~mm}$ may be noticed. For the case of the Służew Creek catchment, the coefficient of determination $\left(R^{2}\right)$ equaled 0.470 and for the Zagożdżonka River catchment it was 0.236.

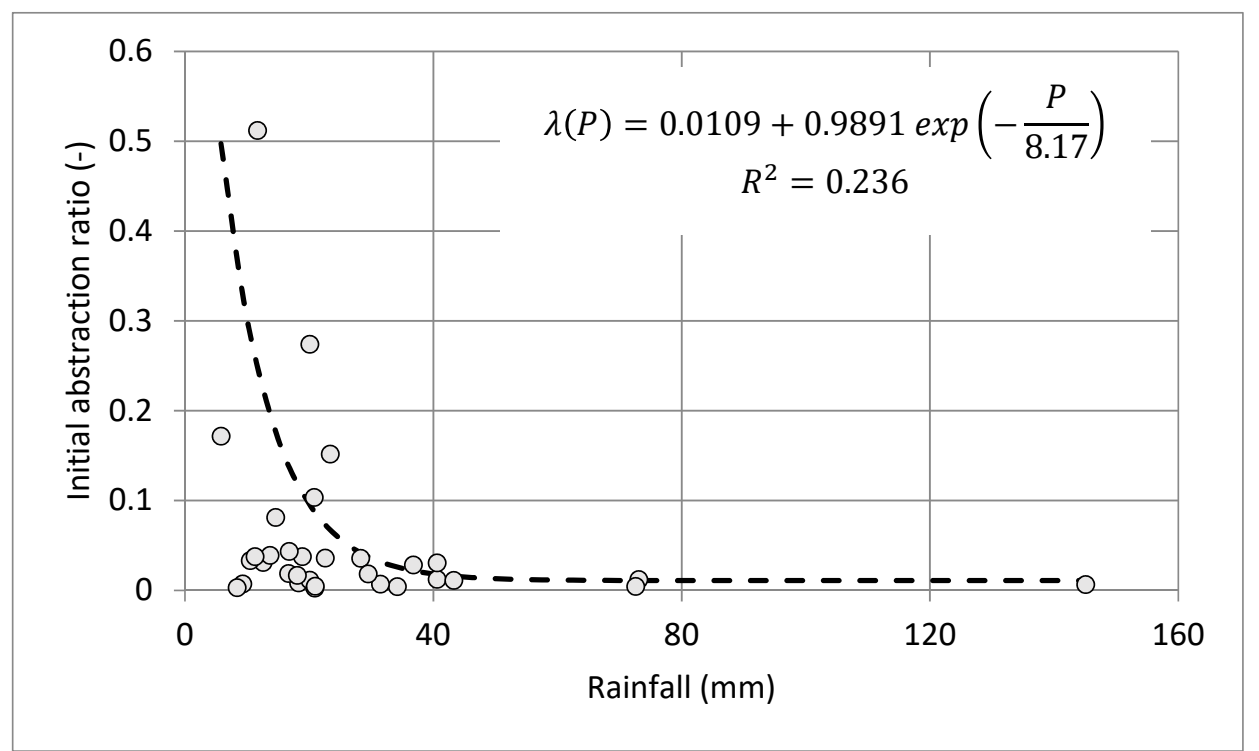

Figure 7. Initial abstraction ratio vs. rainfall depth for summer period, Zagożdżonka River catchment.

Estimations of similar relationships for the other two seasons were not performed due to too few events per season. The relationship between the initial abstraction and the rainfall depth, and the initial abstraction and the maximum potential retention, could not be established for recorded events (no relationship was observed).

A similar phenomenon with the equilibrium in the initial abstraction ratio was observed by Santikari and Murdoch [9] who also found that the initial abstraction amount approaches some constant value after a certain rainfall depth is exceeded. They, however, did not explore the relationship between the initial abstraction ratio and the rainfall depth itself. This phenomenon observed in our data can be explained by the fact that usually after heavy rainfalls, the entire catchment area takes part in the runoff formation. Therefore, the initial abstraction does not increase further and, consequently, the initial abstraction ratio approaches a constant value. In contrast to that, during small rainfalls, only some and often various parts of the catchment contribute to the runoff formation, causing a variation in the initial abstraction ratio. Although usually the catchment area located closest to the channel contributes most to the generated runoff during small rainfall events, the exact catchment contribution depends on the movement of the storm cloud and the detection of the rainfall cloud by local point measurements [54]. Note that the SCS method was originally designed for a direct runoff estimation of large (annual) events, during which the spatial patterns of the rainfall do not play any significant role in the runoff generation [5]. In reference to the above, Hawkins et al. [55] suggested selecting representative events in the watershed, i.e., with rainfall depths higher than 1 inch $(25.4 \mathrm{~mm})$, for analyses of the $C N$ parameter. In our case, we did not limit the selection of events to rainfalls exceeding this threshold value, as this would reduce the number of analyzed events to 13 in Słuziew Creek and 12 in Zagożdżonka River. Application of the SCS-CN method to rainfall events smaller than annual events is a common practice for runoff estimation in ungauged catchments, where other more 
data intensive models cannot be applied $[8,15,33]$. Such applications to small(er) events may, however, result in a lower model performance than that expected by the method, and the reasons for that should always be clarified.

\subsection{Initial Abstraction Ratio May Change Locally}

As our results from recorded storm events in two catchments of different dominant land use type showed, the initial abstraction ratio varies from storm event to storm event, and it is related to the rainfall depth. This ratio also varies seasonally and is linked to the land use type as well as the state of the vegetation. It should also be noted that the method of $I a$ estimation applied for this study is devoted to small catchments, for which the effect of water travel time within the catchment may be neglected. The presented approach does not suit large catchments, where the effect of runoff routing and the effect of the spatial variability of rainfall on the runoff production may play a significant role. Thus, for such large size catchments, the validity of the obtained results may be limited. Hence, more research is needed on the initial abstraction ratio in different climatic regions and also for catchments with different land use types, to verify results found in our study and to compare local estimates with original values (0.2 and 0.05$)$. We suggest that if local information is available, the initial abstraction ratio for the SCS-CN method should be estimated from locally collected data before applying the method to flood estimation or designing flood structures. Of course, estimating the value of $\lambda$ for each event or catchment independently can be problematic in practice especially for ungauged catchments without recorded storm events. However, it should still be possible and reasonable to use an initial abstraction ratio value that is specific for the region or catchment type, if such values are available. In the case of no regional or catchment-type values being available, standard values as originally proposed in the SCS-CN method should be used instead. Such local verification is especially required if the SCS-CN method is applied outside of its original scope, i.e., to storm events smaller than annual floods. Using the originally proposed value of 0.2 for such small storm events may be linked with underestimation of the runoff amount and thus flood risk in catchments, where the estimated value of the initial abstraction ratio is much lower than its original value. If only large annual floods are of interest, we suggest using the value proposed originally, i.e., 0.2 , as our results demonstrated the initial abstraction ratio may indeed produce values close to this original value under some conditions (e.g., large floods) and these conditions should be first verified locally to define the application boundaries for the original value of 0.2 . For instance, one should define the return period of floods for which the original value of 0.2 or 0.05 could still be applied, and the threshold value of the return period above which local estimates are preferable.

\section{Conclusions}

In this work, rainfall-runoff storm events recorded in the period of 2009-2017 in two small Polish catchments of different land use types (urbanized and agroforested) were analyzed to estimate the initial abstraction ratio of the SCS-CN method and to explore its variability with rainfall depth, land use type, and season. Based on our results, the following conclusions have been made:

- Estimated values of the initial abstraction ratio varied between storm events and were most often lower than the original value of 0.20 originally suggested. For the urbanized catchment, this ratio ranged from 0.002 to 0.188 , with the average value of 0.025 , while for the agroforested catchment, the average ratio equaled 0.047 , ranging from 0.001 to 0.512 ;

- The initial abstraction ratio varies over seasons, especially in the case of non-urbanized catchments with a high percentage of area covered with vegetation. Its higher value is expected during the vegetation period due to the occurrence of plants' interception. In urbanized catchments, a variation of the ratio over seasons is expected to be small;

- $\quad$ For large rainfall events, the initial abstraction ratio approaches a constant value after the rainfall depth exceeds a certain threshold value. This threshold is catchment dependent and in the case 
of the urbanized catchment it was $p>30 \mathrm{~mm}(\lambda \rightarrow 0.0089)$ and in the case of the agroforested catchment it was $p>20 \mathrm{~mm}(\lambda \rightarrow 0.0109)$;

- When using the SCS-CN method, special care should be taken to determine the initial abstraction ratio, as the suggested value of 0.20 may be too high. This may result in underestimation of the runoff depth that may have serious consequences in terms of the underestimation of flood risk.

Author Contributions: A.K. and A.S. designed the study. A.K. performed the analysis for Służew Creek and wrote the first draft of the manuscript. A.H. and L.H. performed the analysis for Zagożdżonka River. A.S, A.H., and L.H. All authors have read and agreed to the published version of the manuscript.

Funding: This research was partly supported by the following projects: the grant from Island, Lichtenstein, and Norway through the EEA Financial Mechanism and the Norwegian Financial Mechanism, the research projects N N305 396238 and 2015/19/N/ST10/02665 founded by the National Science Center, Poland (NCN), and the research project KORANET EURRO-KPS founded by the National Center for Research and Development (NCBiR). The support provided by the institutions is gratefully acknowledged. The authors wish to thank the associate editor and two anonymous referees for providing useful comments that helped us to improve this paper.

Conflicts of Interest: The authors declare no conflict of interest.

\section{References}

1. Rabori, A.M.; Ghazavi, R. Urban Flood Estimation and Evaluation of the Performance of an Urban Drainage System in a Semi-Arid Urban Area Using SWMM. Water Environ. Res. 2018, 90, 2075-2082. [CrossRef] [PubMed]

2. Banasik, K.; Gorski, D.; Popek, Z.; Hejduk, L. Estimating the annual sediment yield of a small agricultural catchment in central Poland. In Erosion and Sediment Yields in the Changing Environment; Collins, A.V.G., Horowitz, A.X.L., Stone, M., Walling, D., Eds.; IAHS Publ.: Wallingford, UK, 2012; Volume 256, pp. 267-275.

3. Krajewski, A.; Sikorska-Senoner, A.E.; Ranzi, R.; Banasik, K. Long-Term Changes of Hydrological Variables in a Small Lowland Watershed in Central Poland. Water 2019, 11, 564. [CrossRef]

4. Banasik, K.; Hejduk, L. Long-term changes in runoff from a small agricultural catchment. Soil Water Res. 2012, 7, 64-72. [CrossRef]

5. National Engineering Handbook (NEH). National Engineering Handbook, Part 630 Hydrology; USDA: Washington, DC, USA, 2004.

6. Sikorska, A.E.; Scheidegger, A.; Banasik, K.; Rieckermann, J. Bayesian uncertainty assessment of flood predictions in ungauged urban basins for conceptual rainfall-runoff models. Hydrol. Earth Syst. Sci. 2012, 16, 1221-1236. [CrossRef]

7. Hawkins, R.H. Asymptotic Determination of Runoff Curve Numbers from Data. J. Irrig. Drain. Eng. 1993, 119, 334-345. [CrossRef]

8. Shi, Z.-H.; Chen, L.-D.; Fang, N.-F.; Qin, D.-F.; Cai, C.-F. Research on the SCS-CN initial abstraction ratio using rainfall-runoff event analysis in the Three Gorges Area, China. Catena 2009, 77, 1-7. [CrossRef]

9. Santikari, V.P.; Murdoch, L.C. Including effects of watershed heterogeneity in the curve number method using variable initial abstraction. Hydrol. Earth Syst. Sci. 2018, 22, 4725-4743. [CrossRef]

10. Banasik, K.; Hejduk, L.; Woodward, D.; Banasik, J. Flood peak discharge vs various CN and rain duration in a small catchment. Rocz. Ochr. Srodowiska 2016, 18, 201-212.

11. Li, C.; Liu, M.; Hu, Y.; Shi, T.; Zong, M.; Walter, M.T. Assessing the Impact of Urbanization on Direct Runoff Using Improved Composite CN Method in a Large Urban Area. Int. J. Environ. Res. Public Health 2018, 15, 775. [CrossRef]

12. Singh, P.; Bhunya, P.; Mishra, S.; Chaube, U. A sediment graph model based on SCS-CN method. J. Hydrol. 2008, 349, 244-255. [CrossRef]

13. Gupta, S.K.; Tyagi, J.; Singh, P.; Sharma, G.; Jethoo, A. Soil Moisture Accounting (SMA) based sediment graph models for small watersheds. J. Hydrol. 2019, 574, 1129-1151. [CrossRef]

14. Banasik, K.; Krajewski, A.; Sikorska, A.; Hejduk, L. Curve Number Estimation for a Small Urban Catchment from Recorded Rainfall-Runoff Events. Arch. Environ. Prot. 2014, 40, 75-86. [CrossRef]

15. Kowalik, T.; Walega, A. Estimation of CN Parameter for Small Agricultural Watersheds Using Asymptotic Functions. Water 2015, 7, 939-955. [CrossRef] 
16. Cogliandro, V.; Krajewski, A.; Rutkowska, A.; Porto, P.; Banasik, K. Effect of forest fire on lag time of direct runoff of rainfall in a small catchment in Calabria. Sylwan 2017, 161, 677-684.

17. Azizian, A.; Shokoohi, A. Development of a new method for estimating SCS curve number using TOPMODEL concept of wetness index (case study: Kasilian and Jong watersheds, Iran). Acta Geophys. 2019, 67, 1163-1177. [CrossRef]

18. Woodward, D.E.; Hawkins, R.H.; Jiang, R.; Hjelmfelt, J.A.T.; Van Mullem, J.A.; Quan, Q.D. Runoff Curve Number Method: Examination of the Initial Abstraction Ratio. World Water Environ. Resour. Congr. 2003. [CrossRef]

19. Fu, S.; Zhang, G.; Wang, N.; Luo, L. Initial Abstraction Ratio in the SCS-CN Method in the Loess Plateau of China. Trans. ASABE 2011, 54, 163-169. [CrossRef]

20. Junior, L.C.G.D.V.; Rodrigues, D.B.B.; De Oliveira, P.T.S. Initial abstraction ratio and Curve Number estimation using rainfall and runoff data from a tropical watershed. RBRH 2019, 24, 24.

21. Lim, K.J.; Engel, B.A.; Muthukrishnan, S.; Harbor, J.; Harbor, J. Effects of Initial Abstraction and Urbanization on Estimated Runoff Using CN Technology. JAWRA J. Am. Water Resour. Assoc. 2006, 42, 629-643. [CrossRef]

22. Lal, M.; Mishra, S.; Kumar, M. Reverification of antecedent moisture condition dependent runoff curve number formulae using experimental data of Indian watersheds. Catena 2019, 173, 48-58. [CrossRef]

23. Durán-Barroso, P.; González, J.; Valdés, J.B. Sources of uncertainty in the NRCS CN model: Recognition and solutions. Hydrol. Process. 2017, 31, 3898-3906. [CrossRef]

24. Dey, P.; Mishra, A. Separating the impacts of climate change and human activities on streamflow: A review of methodologies and critical assumptions. J. Hydrol. 2017, 548, 278-290. [CrossRef]

25. Zhai, R.; Tao, F. Contributions of climate change and human activities to runoff change in seven typical catchments across China. Sci. Total. Environ. 2017, 605, 219-229. [CrossRef]

26. Zhou, Y.; Lai, C.; Wang, Z.; Chen, X.; Zeng, Z.; Chen, J.; Bai, X. Quantitative Evaluation of the Impact of Climate Change and Human Activity on Runoff Change in the Dongiiang River Basin, China. Water 2018, 10, 571. [CrossRef]

27. Chen, Z.; Chen, Y.; Li, B. Quantifying the effects of climate variability and human activities on runoff for Kaidu River Basin in arid region of northwest China. Theor. Appl. Climatol. 2013, 111, 537-545. [CrossRef]

28. Lv, X.; Zuo, Z.; Xiao, P.; Ni, Y.; Sun, J. Effects of Climate Change and Human Activity on Runoff in a Typical Loess Gullied-Hilly Region Watershed. Pol. J. Environ. Stud. 2018, 27, 779-785. [CrossRef]

29. Tan, X.; Gan, T.Y. Contribution of human and climate change impacts to changes in streamflow of Canada. Sci. Rep. 2015, 5, 17767. [CrossRef] [PubMed]

30. Ranzi, R.; Caronna, P.; Tomirotti, M. Impact of Climatic and Land Use Changes on River Flows in the Southern Alps. In Sustainable Water Resources Planning and Management Under Climate Change; Kolokytha, E., Oishi, S., Teegavarapu, R., Eds.; Springer: Singapore, 2017; pp. 61-83.

31. Hejduk, L.; Hejduk, A.; Banasik, K. Determination of Curve Number for snowmelt-runoff floods in a small catchment. In Proceedings of the International Association of Hydrological Sciences; IAHS Publ.: Prague, Czech Republic, 2015; Volume 370, pp. 167-170.

32. Banasik, K.; Hejduk, L.; Barszcz, M. Flood flow consequences of land use changes in a small urban catchment of Warsaw. In 11th International Conference on Urban Drainage; IAHR/IWA: Edinburgh, UK, 2008; pp. 1-10.

33. Sikorska, A.; Banasik, K. Parameter identification of a conceptual rainfall-runoff model for a small urban catchment. Ann. Warsaw Univ. of Life Sci. SGGW Land Reclam. 2010, 42, 279-293. [CrossRef]

34. Sikorska, A.E.; Scheidegger, A.; Banasik, K.; Rieckermann, J. Considering rating curve uncertainty in water level predictions. Hydrol. Earth Syst. Sci. 2013, 17, 4415-4427. [CrossRef]

35. Krajewski, A.; Sikorska, A.E.; Banasik, K. Modeling Suspended Sediment Concentration in the Stormwater Outflow from a Small Detention Pond. J. Environ. Eng. 2017, 143, 05017005. [CrossRef]

36. Krajewski, A.; Banasik, K.; Sikorska, A. Stormflow and suspended sediment routing through a small detention pond with uncertain discharge rating curves. Hydrol. Res. 2019, 50, 1177-1188. [CrossRef]

37. Krajewski, A.; Wasilewicz, M.; Banasik, K.; Sikorska, A.E. Operation of detention pond in urban area-example of Wyscigi Pond in Warsaw. In Environmental Engineering V; Pawlowska, M., Pawlowski, L., Eds.; CRC Press: London, UK, 2017; pp. 211-215.

38. Krajewski, A.; Gladecki, J.; Banasik, K. Transport of suspended sediment during flood events in a small urban catchment. Acta Sci. Pol. Form. Circumiectus 2018, 17, 119-127. [CrossRef] 
39. Majewski, G.; Przewoźniczuk, W.; Kleniewska, M. Precipitation at the meteorological station in Ursynów WULS - SGGW in 1960-2009. Sci. Rev. Eng. Env. Sci. 2010, 19, 3-22.

40. Majewski, G.; Odorowska, M.; Rozbicka, K. An analysis of the thermal conditions at Ursynów-SGGW station in Warsaw for the years 1970-2009. Water-Environ.-Rural Areas 2012, 2, 171-184.

41. Department of Water Engineering and Applied Geology (DoWEaAG), Warsaw University of Life Sciences, Warsaw, Poland. Investigations Realised within the Statutory Activity of the DoWEaAG, Funded by the Ministry of Science and Higher Education, in Years 2010-2017, Internal Report; Department of Water Engineering and Applied Geology (DoWEaAG), Warsaw University of Life Sciences: Warsaw, Poland, 2017.

42. Copernicus Land Monitoring Service, CORINE Land Cover 2018. Available online: https://www.copernicus. eu/en/services/landURL (accessed on 1 June 2019).

43. Soil-Agricultural map, 1:500,000, Masovian Spatial Information System. Available online: https://msip. wrotamazowsza.pl/msip/Full.aspx (accessed on 1 June 2019).

44. Kurowska-Łazarz, R.; Szulc, W.; Woźniak, B.; Piotrowska, M.; Drożdżyńska, J. Vademecum. Meteorological MEASUREMENTS and Observations; IMGW-PIB: Warsaw, Poland, 2015; pp. 9-23.

45. Szumiejko, F.; Wdowikowski, M.; Hański, A.; Kańska, A.; Mielke, M.; Aneszko, J.; Jankowska, I.; Wydrych, M. Vademecum. Hydrological Measurements and Observations; IMGW-PIB: Warsaw, Poland, 2015; pp. 13-31.

46. World Meteorological Organisation. Guide to Hydrological Practice, Hydrology-From Measurement to Hydrological Information, 6th ed.; World Meteorological Organisation: Geneva, Switzerland, 2008; pp. I.9-12-I.9-14.

47. Kaznowska, E.; Bansik, K.; Hejduk, A.; Krajewski, A.; Wasilewicz, M.; Hejduk, L.; Gładecki, J. Hydrological characteristics since the mid-twentieth century of a small catchment in southern mazovian region, Poland. In Contemporary Problems of Polish Climate; Chojnacka-Ożga, L., Lorenc, H., Eds.; IMGW-PIB Press: Warszawa, Poland, 2019; pp. 135-146.

48. Wanielista, M.; Kersten, R.; Eaglin, R. Hydrology, Water Quantity and Quality Control; John Wiley\&Sons, Inc.: Wiley: New York, NY, USA, 1997; pp. 189-193.

49. Ling, L.; Yusop, Z.; Yap, W.-S.; Tan, W.L.; Chow, M.F.; Ling, J.L. A Calibrated, Watershed-Specific SCS-CN Method: Application to Wangiaqiao Watershed in the Three Gorges Area, China. Water 2020, 12, 60. [CrossRef]

50. Walega, A.; Michalec, B.; Cupak, A.; Grzebinoga, M. Comparison of SCS-CN determination methodologies in a heterogeneous catchment. J. Mt. Sci. 2015, 12, 1084-1094. [CrossRef]

51. Soulis, K.X.; Valiantzas, J.D. SCS-CN parameter determination using rainfall-runoff data in heterogeneous watersheds-the two-CN system approach. Hydrol. Earth Syst. Sci. 2012, 16, 1001-1015. [CrossRef]

52. Soulis, K.; Valiantzas, J. Identification of the SCS-CN Parameter Spatial Distribution Using Rainfall-Runoff Data in Heterogeneous Watersheds. Water Resour. Manag. 2013, 27, 1737-1749. [CrossRef]

53. Systat Software Inc. TableCurve 2D v5.01 for Windows; Systat Software Inc.: Chicago, IL, USA, 2002.

54. Sikorska, A.; Seibert, J. Value of different precipitation data for flood prediction in an alpine catchment: A Bayesian approach. J. Hydrol. 2018, 556, 961-971. [CrossRef]

55. Hawkins, R.H.; Hjelmfelt, A.T.; Zevenbergen, A.W. Runoff Probability, Storm Depth, and Curve Numbers. J. Irrig. Drain. Eng. 1985, 111, 330-340. [CrossRef]

(C) 2020 by the authors. Licensee MDPI, Basel, Switzerland. This article is an open access article distributed under the terms and conditions of the Creative Commons Attribution (CC BY) license (http://creativecommons.org/licenses/by/4.0/). 